\title{
RESEARCH OF THE ACTUAL ENERGY CONSUMPTION OF THE MILITARY PERSONNEL OF THE ARMED FORCES OF UKRAINE TO SUBSTANTIATE THE CORRECTION OF THEIR DAILY DIET
}

DOI: 10.36740/WLek202103222

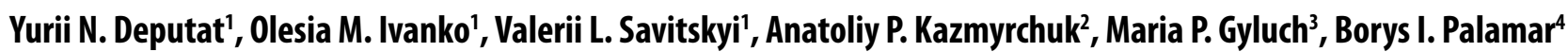 \\ 'UKRAINIAN MILITARY MEDICAL ACADEMY, KYIV, UKRAINE \\ 2NATIONAL MILITARY MEDICAL CLINICAL CENTER “MAIN MILITARY CLINICAL HOSPITAL", KYIV, UKRAINE \\ "STATE INSTITUTION “O.M. MARZIEIEV INSTITUTE FOR PUBLIC HEALTH"NAMSU, KYIV, UKRAINE \\ ${ }^{4}$ BOGOMOLETS NATIONAL MEDICAL UNIVERSITY, KYIV, UKRAINE
}

\begin{abstract}
The aim: Is to determine the actual energy costs of servicemen on the qualification course of special operations of the Armed Forces of Ukraine to substantiate the adequate nutritional and energy value of their diet.

Materials and methods: The actual average daily energy consumption of 85 servicemen of the qualification course (hereinafter - Q-course) of special operations of AF of Ukraine was determined by time-table and instrumental methods. By laboratory, calculation and questionnaire methods, the compensatory possibilities of their actual nutrition were assessed.

Results: The data obtained indicate that the highest indicators of energy expenditures among servicemen were during the first phase of selection of the Q-course at the level of an average value of $6853 \pm 963.9$ kilocalories (hereinafter - $\mathrm{kcal}$ ) per day. At the same time, the calorie content of actual food consumed only by $55.7 \%$ provided compensation for the average daily energy costs.

In this regard, we have developed and implemented "Organizational and Methodological Guidelines for Rational Nutrition of Servicemen of SOF of AF of Ukraine".

Conclusions: The actual nutrition of the military personnel on the Q-course of SOF of AF of Ukraine does not fully compensate for their real energy losses. The nutritional and energy value of the daily diet requires revision and bringing it into line with the actual energy consumption, depending on the preparation phases.
\end{abstract}

KEY WORDS: Special Operations Forces, qualification course, energy costs, diet

Wiad Lek. 2021;74(3 p.II):684-689

\section{INTRODUCTION}

The features of the professional activities of military personnel present increased demands on their health. First of all, this concerns the divisions of the units of SOF, which undergo special training to solve specific tasks in any conditions [1,2]. The fulfillment of the most difficult combat and educational-training tasks for this category of servicemen is associated with high daily energy costs due to physical and psycho-emotional stress, which requires adequate food intake for its compensation. Energy costs and their adequate compensation are a significant indicator of the combat effectiveness of personnel $[3,4]$. The authors $[5,6]$ pay special attention to the study of the issue of the energy needs of servicemen during the training process during the training of SOF. At the same time, the problem of compensation of the energy costs of military personnel, including SOF, in the armed forces of foreign countries remains not fully studied.

The above-mentioned issue was mostly not studied at all in Ukraine, since SOF as a separate component of the Ukrainian Armed Forces were created only in 2016 with the support of NATO member countries [7].
In this regard, scientific research was carried out to study the daily energy consumption and the completeness of its replenishment due to the nutrition of the military personnel of the Ukrainian Armed Forces. The research was carried out as part of the planned research work in 2018 - 2019 on the basis of one of the training centers during the qualification course for special operations of the Armed Forces of Ukraine.

\section{THE AIM}

Determine the actual energy costs of military personnel on the qualification course for training SOF of AF of Ukraine to substantiate the adequate nutritional and energy value of their diet.

\section{MATERIALS AND METHODS}

The training of cadets on the Q-course lasts twenty-three weeks and consists of five phases. The preparation takes place in a continuous cycle, i.e. two courses per calendar year. 


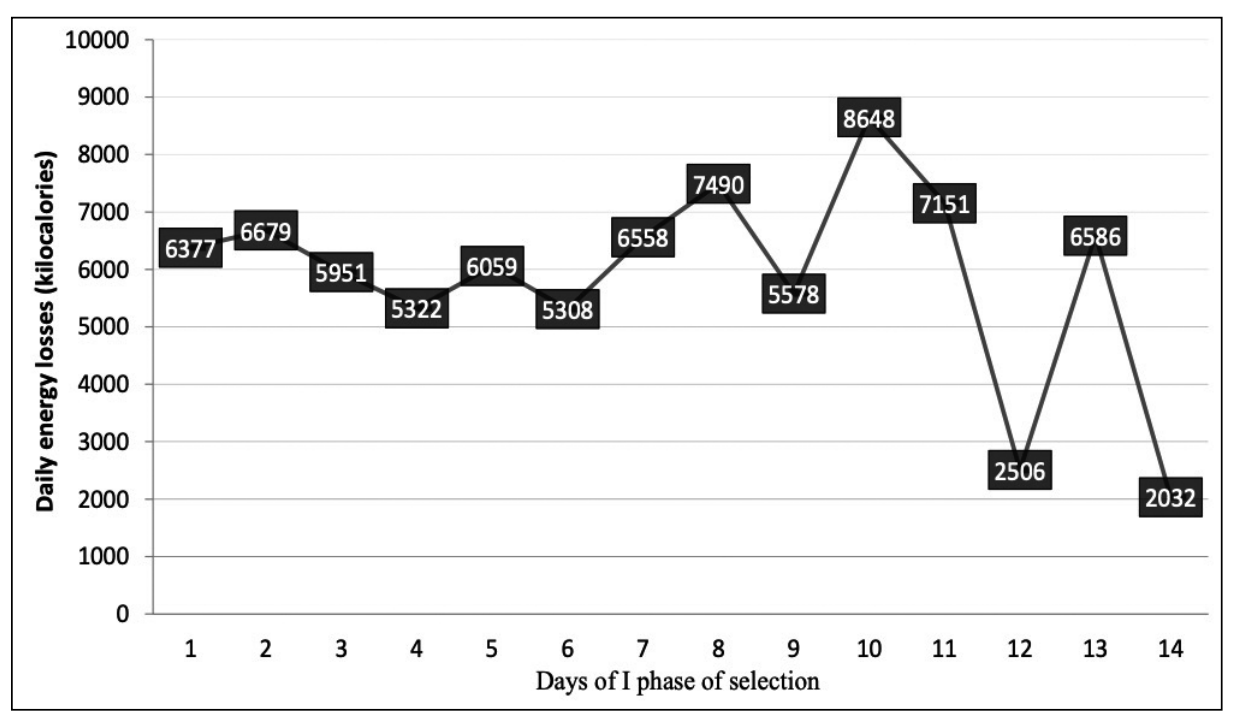

Fig. 1. Average energy losses of servicemen during I phase of Q-course
Scientific research was carried out in three directions. The first investigated the actual average daily energy consumption of servicemen at different phases of the Q-course. For this, the time-table method for determining the daily energy losses was used. The study involved 85 servicemen of the IX qualification course. During the day, the time used for each type of work or rest performed was recorded in detail. At the same time, the tabular coefficient of physical activity corresponding to each type of activity was taken into account, as well as the average indicators of the basic metabolic rate of military personnel, obtained by the calculation method according to the method of WHO $[8,9]$.

When cadets performed various distance tasks (cross-training, marching, topography with orientation on the terrain, etc.), the time-table method for determining the body's energy losses was supplemented by an instrumental method by using special chest and wrist cardiac sensors from Polar and Garmin.

The second direction of research included the study of the issue of adequacy of replenishing the actual average daily energy expenditure of servicemen on the Q-course at the expense of the diet provided to them. The determination of the indicators of the energy and nutritional value of the daily diet was carried out by the calculation method according to the weekly layouts of the products of the military unit using reference tables of the chemical composition of food products [10]. Selected samples of the daily diet and individual dry rations were analyzed by the laboratory method (the norm is 15 - a daily field set of products). In a laboratory study, the protein content in the selected portions of ready meals was determined by the Kjeldahl method [11], the fat content was determined by the extraction method using the Soxhlet apparatus [12]. The actual amount of carbohydrates was determined by the calculation method [13].

The task of the third line of research was to study, using the questionnaire-survey method, the subjective assessment of the state of their nutrition by servicemen and its compliance with the tasks performed on the Q-course. In total, 111 anonymously completed questionnaires were received from male military personnel, of which 85 cadets of the qualification course and 26 military instructors. The age range of the respondents was from 20 to 46 years old.

The data obtained was processed using traditional statistical methods. For all data, statistical processing was carried out: descriptive statistics (calculation of arithmetic means for the initial values and percentages, as well as their errors) and checking for normality. Since the data obeyed a normal distribution, the comparison was carried out using the parametric Student's t-test with the calculation of the corresponding $\mathrm{t}$ and $\mathrm{p}$.

\section{RESULTS}

The determination of the indicators of the average daily energy expenditures of servicemen on the Q-course made it possible to establish that they are a variable value and depend on the training activities performed in different phases of the course according to the training program, as well as on the individual characteristics of the organism of servicemen.

According to our research data, the highest average daily energy expenditures among Q-course cadets were recorded during the two-week phase I of selection, which was caused by the impact of heavy and exhausting physical and mental stress. The characteristic of the average daily energy consumption of servicemen for 14 days of the first phase of the selection of the Q-course is shown in Fig. 1.

Average daily energy consumption for the two-week phase I was $6853 \pm 963.9 \mathrm{kcal}$ (excluding two days of rest).

The averaged data of cadets' energy consumption at different phases of the Q-course are shown in Fig. 2.

At the same time, the maximum average daily energy consumption indicators of Q-course servicemen during phase I $(6853 \pm 963.9 \mathrm{kcal})$ were statistically significantly higher than the corresponding energy consumption indicators for phases II and IV of the Q-course $(\mathrm{p}<0.01)$.

There were no significant differences in the indicators of energy consumption at the I, III, and V phases of the Q-course (Fig. 2), which can be explained by the similarity 

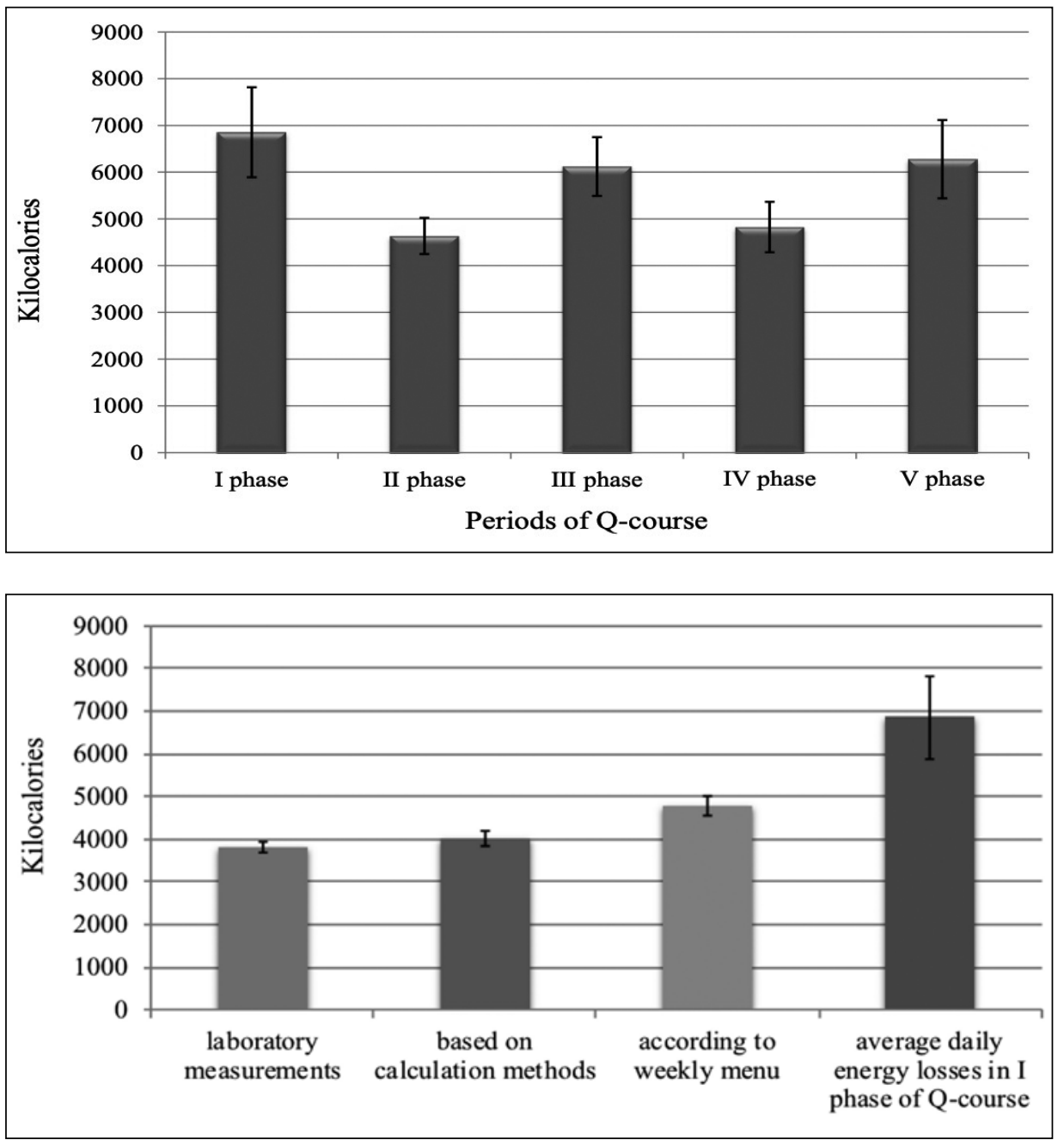

Fig. 2. Average energy losses of servicemen on different phases of $Q$-course

Fig. 3. Average daily data of energy value of actual ration of servicemen compared with energy losses in I phase of Q-course in the severity and intensity of physical activity in these periods of training. Thus, the obtained indicators of the average daily energy consumption of the Q-course cadets during the III phase of the course amounted to $6120 \pm$ $627.3 \mathrm{kcal}$, and during the $\mathrm{V}$ phase of the final training $6277 \pm 837.2 \mathrm{kcal}$.

Despite the small difference in the obtained indicators of energy consumption of cadets in phases I, III, and V, the body's reaction to them, obviously, was different, since, at the beginning of the Q-course (in phase I), adaptive mechanisms to new conditions of life were not yet formed. Besides, in the first phase, the body of servicemen was deliberately subjected to great (sometimes maximum possible) physical and stress loads to select the most resilient and healthy ones.

In general, throughout the entire duration of the Q-course, the average daily energy consumption of servicemen amounted to $5741.8 \pm 671 \mathrm{kcal}$.

Taking into account the indicators of the average daily energy consumption of cadets in the II $(4635 \pm 385.4 \mathrm{kcal})$ and IV phases ( $4824 \pm 541.3 \mathrm{kcal})$ of the Q-course, we can talk about the possibility of compensating them by the actual diet according to the Product Catalog (AD) for this category of people, nutritional standards and compliance with the traditional three-time meal plan.
During phases I, III, and V, it becomes necessary to revise the qualitative and quantitative characteristics of the diet to replenish the high (within $7000 \mathrm{kcal}$ ) energy costs of the Q-course cadets, as well as to change their diet.

The second direction of research included the assessment of the $\mathrm{AD}$ of military personnel during their stay on the Q-course to determine its adequacy to the physical and psycho-emotional loads of cadets and its ability to compensate for real energy costs during the training phases.

It has been established that during training on the Q-course at the training ground of the military unit, the cadets are provided with three hot meals a day, which are prepared in a stationary canteen, and then delivered in thermoses by cooks by motor transport. The food intake by the personnel is organized according to the daily routine in an adapted stationary room, which is equipped with a food delivery line and a dining room. In this case, food for Q-course servicemen is carried out according to the enhanced version (at a price coefficient of 1.2 of the cost of daily food). During the days when the cadets' classes under the Q-course preparation program took place in isolation from the location, food was provided at the expense of norm No. 15 - a daily field set of products (the so-called dry ration).

The results of laboratory studies of AD dishes, which were selected for analysis, indicated that the content of the 
Table I. Diet Composition Data Based on Key Nutrients and Calories

\begin{tabular}{cccccc}
\hline No & Essential nutrients and energy & Laboratory method & Calculation method & Product layout \\
\hline 1 & Proteins, $g$ & $166,9 \pm 8,7$ & $174,1 \pm 12,2$ & - \\
\hline 2 & Fat, $g$ & $112,9 \pm 14,1$ & $128,8 \pm 23,4$ & - \\
\hline 3 & Carbohydrates, g & $533,1 \pm 49,6$ & $540,1 \pm 51,7$ & - \\
\hline 4 & Caloric content, kcal & $3815,7 \pm 141,2$ & $4015,6 \pm 168,4$ & $4776,3 \pm 250,7$ \\
\hline
\end{tabular}

main nutrients and energy in the studied dishes did not fully correspond to the data obtained by calculation when evaluating the layouts of products.

At the same time, the results of the analysis of the content of basic nutrients and energy in the diets of servicemen of the Q-course revealed a moderate, statistically insignificant decrease in the real content (according to laboratory analysis) of the average statistical indicators of proteins, fats, carbohydrates, and energy value in comparison with the calculated data according to the weekly distribution of products (Table I), which testifies to the incomplete correspondence of the $\mathrm{AD}$ of military personnel to the established nutritional composition of the distribution of products, determined by the calculation method.

The reason for the incomplete correspondence of the indicators of the nutrient (proteins, fats, carbohydrates) composition and energy value is most likely a violation of the cooking technology.

Since during phase I the servicemen experienced the greatest (for all periods of the Q-course) need to compensate for energy costs due to adequate food intake, more attention was paid to the comparative analysis between the used and consumed energy by cadets in this phase.

Comparison of the data of the average daily calorie content of the cadets during the I phase, indicated in the weekly layout of the products of the military unit, with the results of analyzes using laboratory and calculation methods against the background of the actual average daily indicator of energy costs in this phase are shown in Fig. 3.

A statistically significant difference of more than $20 \%$ $(\mathrm{p}<0.01)$ was found between the real ones, i.e. laboratory-confirmed indicators of the energy value of $\mathrm{AD}(3815.7 \pm 141.2$ $\mathrm{kcal}$ ) and declared in the layouts of the products of the military unit $(4776.3 \pm 250.7 \mathrm{kcal})$ during the first phase of training.

In addition, the results of laboratory analysis revealed a significant $(p<0.001)$ difference between the indicators of the energy value of the $\mathrm{AD}$ consumed and the average daily energy expenditures of military personnel with the greatest physical and psycho-emotional stress during the 14-day phase I of the selection of the Q-course $(6853 \pm 963.9 \mathrm{kcal})$, indicating only partial (by $55.7 \%$ ) replenishment of energy due to the daily diet. At the same time, a negative energy balance arises in the body, which can pose a threat to the health of cadets, cause a decrease in physical and mental performance, and contribute to the negative impact of adverse environmental factors on the body.

When assessing the actual nutrition of military personnel throughout the entire duration of the Q-course of SOF of AF of Ukraine, the calculation method for the layouts of products established statistically significant $(\mathrm{p}<0.01)$ difference between the indicators of the average daily energy consumption with food $(4424.7 \pm 135.5 \mathrm{kcal})$ and the average daily indicators energy consumption during the course duration $(5741.8 \pm 671 \mathrm{kcal})$.

During field trips, more than 1 day apart from the base camp, Q-course servicemen are provided with daily field food kits - Daily Field Set of Products - Diet (DFSP - D) in an assortment (from DFSP - D1 to DFSP - D14) with a caloric value of at least $3500 \mathrm{kcal}$ [14]

DFSP - D is designed to provide adequate nutrition during the day, in conditions where cooking hot food is impossible. It consists of assorted ready-to-eat meals in four-layer retort bags that ensure the safety and quality of food for 24 months.

On days when nutrition was carried out in an autonomous mode exclusively due to individual dry rations, an energy imbalance appeared in the cadets' bodies, since the daily energy value of DFSP - D averaged $3600 \mathrm{kcal}$, which statistically significantly $(\mathrm{p}<0.01)$ differed from the average daily energy consumption for all periods of the Q-course $5741.8 \pm 671 \mathrm{kcal}$.

In the third direction of research, the results of questioning the cadets of the Q-course showed that only $12,3 \pm 9,7 \%$ of them were completely satisfied with the food, while $73,9 \pm 17,4 \%$ were only partially satisfied $(\mathrm{p}<0,001)$, and $13,8 \pm 10,7 \%$ were not completely satisfied ( $p>0,05)$.

The reason for this, according to $53,6 \pm 22,4 \%$ of the respondents, was the insufficient variety of prepared dishes. At the same time, the majority of candidates $(86,2 \pm 10,7 \%)$ noted satisfaction with the taste properties of food. However, only $2,4 \pm 2,1 \%$ of the respondents believed that the food provided to them can fully compensate for their physical activity, while $59,5 \pm 21,7 \%$ of the respondents $(\mathrm{p}<0,05)$ noted that such food only partially compensates for the load. $44 \pm 22.2 \%$ of candidates constantly, and $31,4 \pm 19,4 \%$ - quite often $(p>0,05)$ had a feeling of hunger between meals in the first phase of selection. Disorders in the work of the gastrointestinal tract after eating were indicated by $47,1 \pm 22,4 \%$ of the respondents, in a third of whom they appeared in the form of heartburn.

$43,2 \pm 22,1 \%$ of the respondents spoke in favor of the need for a complete revision and change of nutrition on the Q-course, $53,1 \pm 22,4 \%$ - for a partial revision of the daily $\operatorname{diet}(\mathrm{p}>0,05)$. According to $68 \pm 19,6 \%$ of respondents, it is necessary to introduce new food products and dishes into the diet to expand the range of food consumed $62,5 \pm 21,1 \%$ of candidates insisted on the necessity of introducing vitamin and mineral complexes in addition to food. When 
asked which food groups it is advisable to improve the daily diet, $81,5 \pm 13,6 \%$ of the respondents noted confectionery, $71,4 \pm 18,4 \%$ - fruits (berries) and nuts, $52,9 \pm 22,4 \%$ - dairy products, $47,1 \pm 22,4 \%$ - natural juices, $40 \pm 21,6 \%$ - meat and meat products, $24,3 \pm 16,6 \%$ - vegetables.

\section{DISCUSSION}

As a result of the research, the real energy costs of servicemen on the Q-course of SOF of AF of Ukraine were determined for the first time, which made it possible to reveal the inconsistency of their actual power supply to full compensation of energy costs. This issue demanded an immediate solution to bring the nutritional and energy value of the Q-course servicemen's nutrition to adequate, relatively their energy consumption, indicators.

Therefore, based on the results obtained, we have developed, approved, and introduced into the practical activities of the command of SOF of AF of Ukraine "Organizational and methodological guidelines for the rational nutrition of servicemen of SOF of AF of Ukraine", which set out the basic requirements for their nutrition on the Q-course of SOF of AF of Ukraine. The Guidelines substantiate the nutritional and energy needs of servicemen, reflect the differences in the nutrient composition of the daily diet associated with high physical and psycho-emotional stress at various stages of training. The results of the work made it possible to develop daily rations adequate to the actual energy consumption, as well as to propose for practical use new approaches to the organization of diet and drinking regimes for cadets on the Q-course of SOF of AF of Ukraine.

All of the above allows us to conclude that the set goals of scientific research have been achieved. However, to carry out such research in the future in the Armed Forces of Ukraine, it is necessary to develop a methodological and material base, since our research was characterized by cumbersomeness and laboriousness, which created certain difficulties for their implementation under time constraints.

At the same time, the prospects of these studies, in our opinion, are beyond doubt, since it is the indicators of the actual energy consumption of servicemen that should be the basis for substantiating the physiological needs of different categories of military specialists in nutrients and energy, followed by the formation of appropriate compensating food rations, which will allow to preserve their health and combat effectiveness at the proper level.

\section{CONCLUSIONS}

1 . The actual diet of servicemen from the average daily (for the entire Q-course) energy value of $4424.7 \pm 135.5 \mathrm{kcal}$ does not fully compensate for their average daily energy consumption during their stay on the course (5741.8 \pm $671 \mathrm{kcal})$.

2. Nutritional and energy value of the daily diet requires revision and bringing it into line with the actual energy consumption of Q-course servicemen, depending on the phases of training.
3. Fulfillment of the provisions of the "Organizational and methodological guidelines for the rational nutrition of servicemen of SOF of AF of Ukraine" developed by us will eliminate the nutritional and energy deficit of the actual diet of the Q-course cadets, and, consequently, preserve their health and combat effectiveness.

\section{REFERENCES}

1. Naumov Yu. Enciclopedia specnaza stran mira [Encyclopedia of special forces of the world]. - H.: Family Leisure Club Publishing House. 2011; $629 \mathrm{p}$. (in Russian).

2. Furtes 0.0. Komplectyvannia syl specialnych operacii: peredovyi dosvid inozemnych armii [Completion of special operations forces: advanced experience of foreign armies]. Bulletin of the National University "Lviv Polytechnic". 2010; 670: 177-183. (in Ukrainian) .

3. Margolis L.M., Rood J., Champagne C. et al. Energy balance and body composition during us army special forces training. Appl. Physiol. Nutr. Metab. 2013; 38: 396-400.

4. Tharion W.J., Lieberman H.R., Montain S.J. at.al. Energy requirements of military personnel. Appetite. 2005; 44: 47-65.

5. Margolis L.M., Crombie A. P., McClung H. L. at al. Energy Requirement sof US Army Special Operation Forces During Military Training. Nutrients. 2014; 6(5): 1945-1955.

6. Palamar B.I., Gruzieva T.S. Criteria of economic effectiveness of preventive measures of chronic non-infectious diseases. Wiadomości Lekarskie. 2018; 71: 897-906.

7. Zakon Ukrainy "Pro vnecennya zmin do deyakych zakoniv Ukrainy schodo Syl special'nych operacii Zbroynych Syl Ukrainy" № 1420-VIII vid lypnya 16, 2016 [Law of Ukraine "On Amendments to Certain Laws of Ukraine Concerning the Special Operations Forces of the Armed Forces of Ukraine" № 1420-VIII from June 16, 2016]. Bulletin of the Verkhovna Rada of Ukraine. 2016; № 31:546 p. (in Ukrainian).

8. Lyapin V.A., Solomka T.N., Kovalenko E.V. Gigienicheskaya ocenka pitaniya: ychebnoe posobie [Hygienic assessment of nutrition: a tutorial]. Omsk: Publishing house of Siberian State University of Physical Culture. 2012; 136 p. (in Russian).

9. Tsypriyan V.I.,Velyka N.V., Yakovenko V.G. Metodyka ocinky harchovogo status lyudyny ta adekvatnosti indyvidyal'nogo harchyvannya [Methods for assessing human nutritional status and adequacy of individual nutrition]. Teaching method. 1999; 60 p. (in Ukrainian).

10. Skurikhin I.M., Volgareva M.N. Himicheskyi sostav pischevych prodyctov: spravochnik [Chemical composition of food: a reference book]. Book 1: V0 "Agropromizdat"; 1987, 223 p. (in Russian).

11. Myaso i mysoprodykty. Metody opredeleniya belka: GOST 25011-2017 [Meat and meat products. Protein determination methods: state standart]. Moscow: Standartinform; 2017, 14 p. (in Russian).

12. Myaso i mysoprodykty. Metody opredeleniya zhira: GOST 23042-2015 [Meat and meat products. Methods for determination of fat: state standart]. Moscow: Standartinform; 2016, 11 p. (in Russian).

13. Yatsula G.S., Slobodkin V.I., Bereza V.Ya. et al. Sanitarno-gigienicheskie metody issledovaniya pischevych prodyktov i vody [Sanitary and hygienic methods of study of food and water]. Zdorov'ya. 1991; $288 \mathrm{p}$. (in Russian).

14. Raciony dobovogo polyovogo nabory prodyktiv - DPNP-R. Texnichni umovy TU U 10.8-00034022-201:2018 [Rations of daily field set of products - DFSP - D. Technical conditions 10.8-00034022-201: 2018]. Valid from 04.10.18. Ministry of Defense of Ukraine. 2018, 45 p. (in Ukrainian). 
The studies were carried out as part of the planned research work "Physiological and hygienic substantiation of the nutritional composition of the daily diet of servicemen of the Special Operations Forces", code "SOFAS", (2018-2019, state registration No. 0118U000702). Funding for research work was carried out at the expense of maintenance (salary), no additional sources of funding were allocated.

\section{ORCID and contributionship:}

Yurii N. Deputat: 0000-0002-8189-9366 ${ }^{A, B, D}$

Olesia M. Ivanko: 0000-0002-5929-255X A, B,D,E,F

Valerii L. Savitskyi: 0000-0002-5929-255X ${ }^{A, B} D$

Anatoliy P. Kazmyrchuk: 0000-000278300818 ${ }^{A, B, D}$

Maria P. Gyluch: 0000-0002-1708-3012 A, B,D

Borys I. Palamar: 0000-0003-2510-0713 ${ }^{A, B, D, E, F}$

\section{Conflict of interest:}

The Authors declare no conflict of interest.

\section{CORRESPONDING AUTHOR}

Borys I. Palamar

Bogomolets National Medical University

13, Taras Shevchenko Blvd, 01601 Kyiv, Ukraine

tel: +380672387654

e-mail: palamar.bi@ukr.net

Received: 22.11 .2020

Accepted: 10.03.2021

A - Work concept and design, B - Data collection and analysis, C - Responsibility for statistical analysis,

D-Writing the article, $\mathbf{E}$-Critical review, $\mathbf{F}$ - Final approval of the article 